\title{
Hubungan Beban Kerja Dengan Tingkat Stres Perawat Ruang Intensive Care Unit dan Instalasi Gawat Darurat
}

\author{
Nonik Eka Martyastuti ${ }^{1}$, Isrofah ${ }^{2}$, Khalilatun Janah ${ }^{3}$ \\ 1,2 Universitas Pekalongan \\ ${ }^{3}$ Rumah Sakit Umum Siaga Medika Pemalang
}

\begin{tabular}{|c|c|}
\hline Article Info & Abstract \\
\hline $\begin{array}{l}\text { Article History: } \\
\text { Accepted April 22nd } 2019 \\
\text { Key words: } \\
\text { Workload; Stress Level; } \\
\text { Nurse }\end{array}$ & $\begin{array}{l}\text { The workload in the room is not always a cause of stress on nurses, the } \\
\text { workload will be a source of stress if the number of workloads is not } \\
\text { proportional to the ability of both the physical or expertise and the time } \\
\text { available to nurses. Besides, nurses are faced with patients who trigger an } \\
\text { increasing stress on nurses. This research was conducted at Siaga Medika } \\
\text { General Hospital in Pemalang. The research design used quantitative } \\
\text { associative analytic through cross-sectional approach. The sample of this } \\
\text { study was } 45 \text { nurses who served in the Intensive Care Unit and Emergency } \\
\text { Departments because the nurses' stress levels were higher than the nurses' } \\
\text { stress levels in the other treatment rooms (ward) obtained through total } \\
\text { sampling because the population was less than 100, so that all population } \\
\text { used as research samples. The Work Stress research instrument used the } \\
\text { standard Depression Anxiety Stress Scale questionnaire, while the } \\
\text { workload questionnaire adopted the previous research and was modified. } \\
\text { The results showed that there was a correlation between workload and } \\
\text { stress level of Intensive Care Unit nurses and stress of Emergency } \\
\text { Departments nurses. This showed that nurses who have a heavy workload } \\
\text { that is not comparable to the duties of nurses with the average number of } \\
\text { patients, the number of types of work that must be done. If this is not } \\
\text { managed properly, it will cause increased stress.H This is what becomes } \\
\text { the workload of Intensive Care Unit and Emergency Departments nurses in } \\
\text { Siaga Medika General Hospital in Pemalang which can cause an increase of } \\
\text { stress. }\end{array}$ \\
\hline
\end{tabular}

\section{PENDAHULUAN}

Perawat merupakan seseorang yang telah lulus pendidikan perawat dan memiliki kemampuan serta kewenangan melakukan tindakan keperawatan berdasarkan bidang keilmuan yang dimiliki dan memberikan pelayanan kesehatan secara holistic dan profesional untuk individu sehat maupun sakit, perawat berkewajiban memenuhi kebutuhan pasien meliputi bio-psiko-sosio dan spiritual. Profesi perawat bekerja di tempat pelayanan- pelayanan kesehatan, baik dinstansi pemerintah maupun di instansi swasta.

Pelayanan di ruang Instalasi Care Unit (ICU) dan Instalasi Gawat Darurat merupakan

Corresponding author:

Nonik Eka Martyastuti

nonikekamartyastuti@yahoo.co.id

Jurnal Kepemimpinan dan Manajemen Keperawatan, Vol 2 No 1, May 2019

DOI: http://dx.doi.org/10.32584/jkmk.v2i1.266

e-ISSN 2621-5047 
salah satu ruang rawat di rumah sakit yang dilengkapi staf yang khusus dan perlengkapan yang khusus yang ditujukan untuk observasi, perawatan dan terapi pasien yang menderita penyulit yang mengancam nyawa atau potensial mengancam nyawa dan masih mempunyai harapan hidup. Ruang ICU menurut keputusan Menteri Kesehatan Nomor 1778/MENKES/SK/XII/2010 adalah suatu bagian dari Rumah Sakit yang mandiri, dengan staf khusus dan peralatan khusus yang ditujukan untuk observasi, perawatan dan terapi pasien-pasien yang menderita penyakit dan cedera atau penyulit-penyulit yang mengancam nyawa atau potensial mengancam nyawa dengan prognosis dubia. Ruang ICU menyediakan kemampuan dan sarana, prasarana serta peralatan khusus untuk menunjang fungsi-fungsi vital dengan menggunakan ketrampilan staf medik, perawat dan staf lain yang berpengalaman dalam pengelolaan keadaan-keadaan tersebut.

Fenomena stres kerja sudah menjadi masalah didunia. Hal ini bisa dilihat dari kejadian stres di Inggris terhitung ada 385.000 kasus, di Wales 11.000 sampai 26.000 kasus (Health \& Safty Executive, 2013). Dari empat puluh kasus stres kerja,stres kerja pada perawat berada diurutan paling atas dan perawat juga dapat berpeluang mengalami minor psyciatric disorder dan depresi (American national association for occupational Health, 2009).

Penelitian yang dilakukan oleh PPNI sekitar $50,9 \%$ perawat yang bekerja di empat propinsi mengalami stres kerja, sering pusing, tidak bisa istirahat karena beban kerja terlalu tinggi dan menyita waktu, serta gaji rendah tanpa diikuti intensif yang memadai, tetapi keadaan yang paling mempengaruhi stres perawat adalah kehidupan kerja (PPNI, 2008 dalam Desima, 2013).

Menurut hasil penelitian World Health Organization menyatakan bahwa perawatperawat yang bekerja di rumah sakit di Asia
Tenggara termasuk indonesia memiliki beban kerja berlebih akibat dibebani tugastugas non keperawatan. Perawat yang diberi beban kerja berlebih dapat berdampak kepada penurunan tingkat kesehatan, motivasi kerja, kualitas pelayanan keperawatan, dan kegagalan melakukan tindakan pertolongan terhadap pasien. Apabila waktu bekerja yang harus ditanggung oleh perawat melebihi dari kapasitasnya, seperti banyaknya waktu lembur, akan berdampak buruk bagi produktifitas perawat tersebut (Syaer, 2010)

Penyebab stres yang sering terjadi pada petugas kesehatan meliputi kerja shift, jam kerja yang panjang, peran yang ambigu dan konflik peran, dan terpaparnya petugas kesehatan terhadap infeksi dan substansi bahaya lainya yang ada di rumah sakit. Beberapa penelitian tentang stres kerja terhadap perawat juga telah dilakukan berhubungan dengan beban kerja berlebih (work overload), tuntutan waktu pengerjaan tugas yang cepat, tidak adanya dukungan sosial dalam bekerja (khususnya dari supervisor, kepala perawat dan managerial keperawatan yang lebih tinggi), terpapar penyakit infeksi, tertusuk jarum, dan berhubungan dengan pasien sulit atau kondisi sulit pasien yang serius (NIOSH, 2008 dalam Mutmainah, 2012)

Studi pendahuluan yang dilakukan di RSU Siaga Medika Pemalang pada bulan Oktober 2018, beban kerja perawat ICU dan IGD terhitung tinggi, dengan perbandingan jumlah perawat dan jumlah pasien yang ada tidak seimbang, dan didukung dari hasil perhitungan beban kerja perawat ICU dan IGD menurut Direktorat Pelayanan Keperawatan Dirjen Yan-Med Depkes RI (2001) dengan memperhatikan unit kerja, kebutuhan perawat di ICU seharusnya sebanyak 28 orang, kondisi jumlah perawat yang ada 22 orang dengan jumlah rata-rata pasien perhari sebanyak 11 pasien, demikian juga seharusnya kebutuhan jumlah perawat IGD 37 orang, kondisi yang ada jumlah perawat yang ada 23 orang 
dengan jumlah pasien rata-rata perhari 50 pasien sehingga banyaknya keluhan dari pasien dan keluarga. Itu disebabkan karena aktifitas di ruang ICU mempunyai tanggung jawab besar dalam menangani pasien kritis, kondisi pasien yang kritis menambah beban perawat Ruang ICU lebih besar dibandingkan dengan perawat ruang lainya, karena memerlukan pengawasan dan observasi lebih ketat.

\section{METODE}

Penelitian ini menggunakan desain penelitian kuantitatif asosiatif analitik dengan pendekatan Cross Sectional. Penelitianinidilaksanakan di Rumah Sakit Umum Siaga Medika Pemalang. Sampel dalam penelitian ini adalah perawat di ruang IGD dan ruang ICU sevanyak 45 responden, yang didapatkan memalui total sampling.Proses penelitian berlangsung dari bulan Agustus 2018 sampai dengan Januari 2019.

Instrumen penelitian yang digunakan adalah kuisioner Depression Anxiety Stress Scale (DASS) yang sudah baku dengan jumlah pernyataan unfavourabel 42 item , dengan bentuk skala model likert yang mempunyai jawaban 0 sampai 3 , dimana jawaban dengan nilai $0=$ tidak pernah, $1=$ kadang-kadang, $2=$ sering, $3=$ sering sekali. Pengukuran beban kerja perawat ruang ICU dan IGD menggunakan kuesioner yang sudah dimodifikasi dengan dua kuesioner yang berbeda untuk beban kerja perawat ruang ICU dan IGD, dengan jumlah pernyataan masing- masing kuesioner ada 20 item, dengan bentuk skala model likert, dimana jawaban dengan nilai $1=$ tidak menjadi beban kerja, 2= beban kerja ringan, $3=$ beban kerja sedang, $4=$ beban kerja berat. Sedangkan kuesioner beban kerja, peneliti mengadopsi dari penelitian sebelumnya dengan memodifikasi. Kuesioner beban kerja dilakukan uji validitas di RS Prima Medika Pemalang pada tanggal 29-31 Desember 2018. Hasilnya seluruh pernyataan yang diuji 20 item dinyatakan valid karena memenuhi nilai $p$ value $<0,05$.

\section{HASIL}

Karakteristik Responden

Tabel 1

Karakteristik Responden di Ruang ICU dan IGD RSU Siaga Medika Pemalang

\begin{tabular}{|c|c|c|}
\hline Indikator & f & $\%$ \\
\hline \multicolumn{3}{|l|}{ 1. Jenis Kelamin } \\
\hline a. Laki-laki & 10 & 22 \\
\hline b. Perempuan & 35 & 77 \\
\hline \multicolumn{3}{|l|}{ 2. Usia } \\
\hline a. Usia 21-30 & 35 & 77,8 \\
\hline b. Usia $30-40$ & 10 & 22,2 \\
\hline \multicolumn{3}{|l|}{ 3. Pendidikan } \\
\hline a. DIII Kep & 40 & 88,9 \\
\hline b. S1 Kep & 5 & 11,1 \\
\hline \multicolumn{3}{|l|}{ 4. Status Pernikahan } \\
\hline a. Belum menikah & 25 & 55,6 \\
\hline b. Menikah & 20 & 44,4 \\
\hline \multicolumn{3}{|l|}{ 5. Lama Bekerja } \\
\hline a. 1-3 tahun & 20 & 44,4 \\
\hline b. 4-6 tahun & 20 & 44,4 \\
\hline c. $<6$ tahun & 5 & 11,1 \\
\hline \multicolumn{3}{|l|}{ 6. Beban Kerja } \\
\hline a. Ringan & 24 & 53.3 \\
\hline b. Berat & 21 & 46.7 \\
\hline \multicolumn{3}{|l|}{ 7. Tingkat Stres } \\
\hline a. Ringan & 19 & 42.2 \\
\hline b. Sedang & 26 & 57.8 \\
\hline
\end{tabular}

Karakteristik responden sejumlah 45 orang didominasi perawat laki-laki sebanyak 35 orang ( $77 \%$ ), dengan usia antara 21-30 tahun sebanyak, 35 reponden ( $77,8 \%$ ), pendidikan responden lebih didominasi jenjang D III Keperawatan sebanyak 40 responden ( 88,9\%). Sedangkan dari data Status pernikahan 25 responden ( $55,6 \%$ ) belum menikah. Rata rata dari lama bekerja sebanyak 1- 3tahun 20 responden $(44,4 \%)$ dan hasil yang sama 4-6 tahun sejumlah 20 responden ( $44,4 \%)$.

Hasil penelitian menunjukan bahwa dari 45 responden beban kerja ringan sebanyak 24 $(53,3 \%)$ responden dan yang memiliki beban kerja berat sebanyak 21 (46,7\%) responden. Hasil penelitian menunjukkan bahwa dari 45 responden tingkat stres ringan $19(42,2 \%)$ responden dan memiliki tingkat stres sedang $26(57,8 \%)$ responden. 
Tabel 2

Hubungan beban kerja dengan tingkat stres perawat Ruang ICU dan IGD RSU Siaga MedikaPemalang

\begin{tabular}{cccc}
\hline \multirow{2}{*}{ Beban Kerja } & \multicolumn{2}{c}{ Tingkat Stres } & \multirow{2}{*}{$\mathbf{p}$} \\
\cline { 2 - 3 } & Ringan & Sedang & \\
\hline Ringan & 15 & 9 & \multirow{2}{*}{0,008} \\
Berat & 4 & 17 & \\
\hline Total & 19 & 26 & \\
\hline
\end{tabular}

Hasil penelitian dengan uji statistik chisquere dengan rumus Continuity Correlation. diperoleh responden yang memliki beban kerja ringan dan tingkat stres ringan ada 15 $(33,3 \%)$ responden, yang memiliki beban kerja ringan dan tingkat stres sedang sejumlah $9(20,0 \%)$ responden,jumlah total responden yang memiliki beban kerja ringan dan tingkat stres ringan dan sedang ada $24(53,3 \%)$, jumlah total respoden yang memiliki beban kerja ringan dan berat dan tingkat stres ringan ada $19(42,2 \%)$ yang memiliki beban kerja berat dengan tingkat stres ringan ada 4 (8,9\%) responden, sedangkan yang memiliki beban kerja berat dengan tingkat stres sedang ada 17 (37,8\%) responden. Jumlah total responden yang memiliki beban kerja berat dengan tingkat stres ringan dan sedang ada 21(46,7\%) dan jumlah total responden dengan beban kerja ringan dan berat ada $26(57,8 \%)$. Total semua responden ada $45(100 \%)$.

\section{PEMBAHASAN}

Hasil penelitian yang dilakukan Bawotong, J. et. All, bahwa jumlah perawat usia kurang dari 32 tahun lebih banyak dibanding yang lebih dari 32 tahun, disebabkan kinerja perawat baru lebih rendah dibanding perawat usia lebih dari 32 tahun, sehingga banyak sekali perawat dewasa muda yang keluar masuk. Hal ini di karenakan banyaknya perawat adalah perempuan, serta kebijakan Rumah Sakit yang menetapkan semua perawat ruang ICU adalah perempuan. Didukung dengan hasil penelitian sebelumnya oleh Malara. R.T, et All, (2016) bahwa rasio jumlah perawat perempuan lebih banyak dibanding laki-laki karena jumlah perawat secara umum memang lebih banyak perempuan. Hal ini sesuai dengan pendapat yang di ungkapkan Dauglas (1994) dalam Septiyan, A. (2015) dunia keperawatan sangat didominasi olehperempuan. Hal ini yang menyebabkanberpontensiuntukterjadi stress kerja.

Menurut status pernikahan jumlah responden yang belum menikah lebih banyak ada 25 (55.6\%) responden dibandingkan jumlah responden yang sudah menikah yaitu ada $20 \quad(44,4 \%)$ responden. Ini disebabkan banyaknya perawat baru yang baru lulus sehingga sebagian besar perawat adalah yang masih belum menikah. Sejalan dengan penelitian oleh Septiyan, A. (2015) bahwa perawat sebagian besar belum menikah karena di RS Eka Hospital pengrekrutan perawat sebagian langsung dari lulusan baru di suatu Universitas.

Menurut indikator masa kerja responden di bagi 3 , dengan jumlah responden yang masa kerjanya 1-3 tahun ada $20 \quad(44,4 \%)$ responden jumlah ini sama dengan responden yang lama kerjanya 4-6 tahun yaitu $20(44,4 \%)$ responden sedangkan jumlah perawat yang lama kerjanya $>$ dari 6 tahun hanya sejumlah $5 \quad(11,1 \%)$ responden. Penyebabnya adalah RSU Siaga Medika Pemalang baru berdiri 7 tahun jadi kebanyakan perawat yang ada adalah masa kerja 1-3 tahun dan 4-6 tahun, hal ini sejalan dengan penelitian yang di lakukan oleh Septiyan A, (2015).

Uji statistik chi-squere berdasarkan nilai Continuity Correction $p$ Value 0.008 ( $p<$ 0.05 ) artinya ada hubungan antara beban kerja dengan tingkat stres perawat ruang ICU dan IGD RSU Siaga Medika Pemalang. Diperoleh hasil dari 45 responden, dimana perawat yang beban kerjanya ringan 24 (53\%), yang terdiri dari 15 (33,3\%) stres ringan dan $9(20,0 \%)$ stres sedang. Hal ini menunjukan bahwa sebagian responden merasa tugas yang terlalu banyak dikerjakan dirumah sakit masih terasa ringan, Sedangkan perawat pelaksana yang beban kerjanya berat sebanyak $21(46,7 \%)$, 
yang terdiri dari $19(42,2 \%)$ stres ringan dan $26(57,8 \%)$ stres sedang.

Dari hasil penelitian diatas sejalan dengan penelitian Wagiu F. et all (2017) tentang analisis hubungan antara beban kerja dengan stres kerja pada perawat di ruang rawat inap rumah sakit Hermana Lembean.

Beberapa faktor yang menyebabkan perawat dengan beban kerja yang berat kemudian mengalami stres antara lain kurangnya jumlah perawat sehingga menyebabkan tingginya pelimpahan tugas pekerjaan yang tidak seimbang di ruang ICU dan IGD RSU Siaga Medika Pemalang, ditambah kurangnya perawat yang mempunyai kompetensi khususnya perawat Ruang ICU yang hanya memiliki beberapa perawat yang bersertifikat pelatihan ICU sehingga mereka merasa tidak mampu dalam menangani pasienpasien kritis yang ada di ruang ICU, hal inidirasakan oleh perawat IGD yang kebanyakan adalah perawat baru yang belum berpengalaman sehingga saat menerima pasien di IGD yang dalam kondisi kritis dan gawat darurat merasa kebingungan, dan merasa tidak mampu dengan pelimpahan tugas yang dibebankan pada perawat.Oleh karena itu diperlukan adanya manajemen sumberdaya manusia di rumah sakit untuk mencegah timbulnya stres bagi perawat, berupa dukungan dari pihak-pihak terkait di rumah sakit (Yanto \& Rejeki, 2017).

Dari rumus perhitungan kebutuhan tenaga perawat diruang Intensive Care Unit (ICU) dan Instalasi Gawat Darurat (IGD), didapatkan jumlah tenaga perawat yang dibutuhkan di ruang Intensive Care Unit (ICU) RSU Siaga Medika Pemalang 27 perawat yang dibagi shift pagi, shift sore dan shift malam. Hal ini mengidentifikasi jumlah rasio perawat belum sebanding dengan jumlah rata-rata pasien perhari. Dimana seharusnya rasio perawat klien di Intensive Care Unit yaitu 1 : 1, demikian juga jumlah perawat ruang Instalasi Gawat Darurat (IGD) RSU Siaga Medika Pemalang sebanyak 23, sedangkan menurut perhitungan kebutuhan perawat IGD sebanyak 32 perawat dengan jumlah ratarata pasien perhari 50 pasien, juga tidak sebanding. Dalam kenyataan yang didapatkan dari hasil penelitian jumlah perawat yang memiliki beban kerja ringan cenderung memiliki tingkat stres ringan sebanyak $15 \quad(33,3 \%)$ responden, sedangkan perawat yang memilki beban kerja berat cenderung lebih banyak yang memiliki tingkat stres sedang sebanyak 17 (37,8\%)responden(Nursalam, 2011).

Hasil penelitian ini merupakan indikator diperlukan adanya pengelolaan stres perawat di rumah sakit. Pengelolaan stres perawat dapat meningkatkan kualitas pelayanan yang ada di rumah sakit (Yanto \& Rejeki, 2017). Peningkatan kualitas pelayanan keperawatan yang ada di rumah sakit dapat menurunkan angka revisit pasien (Kustriyani, Andyana, \& Winarti, 2018).

\section{SIMPULAN}

Faktor yang membuat perawat memiliki beban kerja berat meliputi tidak sebandingnya tugas perawat dengan jumlah rata-rata pasien, banyaknya tugas dari pimpinan yang harus diselesaikan dalam batas waktu yang ditetapkan, banyaknya jenis pekerjaan yang harus dilakukan demi keselamatan pasien, dan merasa terbebani terhadap tuntutan pelayanan kesehatan yang berkualitas. Jika hal seperti ini tidak dikelola dengan baik, maka akan berakibat terjadinya stres yang meningkat. Hal inilah yang menjadi beban kerja perawat ruang ICU dan IGD RSU Siaga Medika Pemalang yang dapat menyebabkan timbulnya peningkatan stres.

Beban kerja yang berat merupakan pemicu timbulnya stres, sebab setiap orang memiliki keterbatasan baik dari segi pengetahuan ataupun ketrampilan dan kemampuan fisik, dimana apabila pekerjaan yang banyak dan membutuhkan penyelesaian dalam waktu yang cepat akan 
akan membuat pekerjaan kurang tepat (kesalahan), kesalahan dalam melakukan pekerjaan apalagi pelayanan kepada pasien dirumah sakit dapat mengakibatkan efek yang fatal bagi pasien.

\section{REFERENSI}

American Association of Critical Care Nurse. 2009. AACN Scope and standards for acute and critical care nursing practice. Columbia: AACN

Andriani.D.2013.Tingkat stres perawat pelaksana di ruang ICU RS Adi Husada Undaan Wetan Surabaya.From : andridewi64@gmail.com.1922

Chaterina. 2012. Hubungan Beban Kerja dengan Kinerja Karyawan offshore pada Divisi quality Assurance Quality Control di Pertamina Hulu Energi ONWJ LTD Jakarta. Jakarta : Fakultas Ilmu Sosial dan Ilmu Politik Program Sarjana Ekstensi Program Studi Ilmu administrasi Niaga depok

Desima. R. 2013.Tingkat stres kerja perawat dengan perilaku caring perawat.Jurnal keperawatan. Januari. 43-55

Depkes RI. 1999. Pedoman uraian tugas tenaga kesehatan di rumah sakit.Jakarta: Dirjen Yanmed

Hawari Dadang. 2011. Manajemen Stres; Cemas dan Depresi. Jakarta : Balai Penerbit FKUI

Heath and Safety Executive work Related Stres Anxiety And Depression Statistic in Great Britain 2013: 205

Hidayat, AAA. 2012. Pengantar Konsep dasar Keperawatan. Jakarta : Salemba Medika

Hudak, C. M. \& Gallo, B. M. 2010. Keperawatan kritis: Pendekatan holistik volume 1 (ed. 6). (M. Ester, Editor) (Asih, Penerjemah). Jakarta: EGC

Indriyani, A. 2009. Pengaruh Konflik Peran Ganda \& Stres Kerja Terhadap Kinerja Perawat Wanita di Rumah Sakit. Tesis. Fakultas Manajemen Universitas Diponegoro.

Kemenkes RI. 2010. Pelayanan Kesehatan

Khairun A. R. 2015. Perbedaan caring perawat IGD dan rawat inap kelas III pada kepuasan pasien RSUD Goeteng Taroenadibrata Purbalingga.
Purwokerto : fakultas Ilmu Kesehatan Universitas Muhamadiyah Purwokerto

Kristyaningsih, et. All. 2015. Perbedaan Tingkat Stres Kerja Perawat Instalasi gawat darurat dan unit rawat inap di rumah sakit pancaran GMIM. Maret.1-6

Kozier, et. All. 2010. Fundamental of Nursing : Concepts, Process, and Practice.Jakarta : ECG

Kustriyani, M., Andyana, S., \& Winarti, R. (2018). The Correlation Between The Quality of Health Services And The Involvement of Re-Visit Patients in Public Healthcare. Media Keperawatan Indonesia, 1(3), 24-31. https://doi.org/10.26714/mki.1.3.2018.2431

Leininger, M.M. 1998. Care : The Essense of Nursing and Health Thorofare NS : Charles B. Slack.

Malara, R. T. 2016. Hubungan Peran Perawat Sebagai Care Giver Dengan Tingkat Kepuasan Pasien Instalasi Gawat Darurat Di RSU. GMIBM Monompia Kota Mobagu kabupaten Bolaang Mongondow : ejournal Keperawatan (e-Kp) Volume 4 Nomor 2, Agustus 2016

Munandar, A.S. 2008. Psikologi Industri \& Organisasi. Jakarta : UI Press Muslimah. 2015. Hubungan Beban Kerja dengan Kinerja Perawat di RuangRawat Inap RSUD DR. Rasidin Padang. Padang : Fakultas Keperawatan Universiatas Andalas

Muthmainah, Iin. 2012. Faktor-faktor Penyebab Stres Kerja di Ruangan ICU Pelayanan Jantung Terpadu dr. Cipto Mangukusuma. Depok :Fakultas Ilmu Keperawatan Program Studi Sarjana Keperawatan.

Nursalam. 2015. Manajemen Keperawatan Edisi 4.Jakarta: Medika Salemba.

Peraturan Menteri dalam Negeri. 2008. Tentang Analisis Beban Kerja No. 12 Tahun 2012

Republik Indonesia. 2014. Undang-undang No.20 Tahun 2014 Tentang praktik keperawatan

Republik Indonesia. 2010. Kepeutusan Menteri Kesehatan Nomor 1778/MENKES/SK/XII/2010 Tentang Pedoman Penyelenggaraan Pelayanan Intensive Care Unit(ICU) Di Rumah Sakit

Republik Indonesia. 2009. Keputusan Menteri Kesehatan Nomor 856/MENKES/SK/IX/2009

Nonik Eka Martyastuti - Hubungan Beban Kerja Dengan Tingkat Stres Perawat Ruang Intensive Care Unit dan Instalasi Gawat Darurat 
Tentang Standar instalasi Gawat Darurat di Rumah Sakit.

Yanto, A., \& Rejeki, S. (2017). The Related Factors To Decreased The New Graduate Nurses Work
Stress Level In Semarang. Nurscope: Jurnal Penelitian Dan Pemikiran Ilmiah

Keperawatan, 3(2), 1. 